\title{
ENZYME ACTIVITY ANALYSES OF ANAEROBIC FERMENTED SEWAGE SLUDGES
}

\author{
KARDOS, L. ${ }^{1}$ * - JUHÁSZ, Á. ${ }^{1}$ - PALKÓ, GY ${ }^{2}$ - OLÁH, J. ${ }^{2}$ - BARKÁCS, K. ${ }^{3}$ - ZÁRAY, GY. ${ }^{3}$ \\ ${ }^{I}$ Department of Soil Science and Water Management, Corvinus University of Budapest \\ H-1118 Budapest, Villányi út 29-43., Hungary \\ (phone: +36-1-482-6466; fax: +36-1-428-6336) \\ ${ }^{2}$ Budapest Sewage Works Ltd. \\ H-1087 Budapest, Asztalos Sándor utca 4., Hungary \\ (phone: +36-1-455-4100; fax: +36-1-459-1600) \\ ${ }^{3}$ Cooperative Research Center for Environmental Sciences, Eötvös Loránd University \\ H-1117 Budapest, Pázmány Péter sétány 1/a, Hungary \\ (phone: +36-1-372-2607; fax: +36-1-372-2608) \\ *Corresponding author \\ e-mail: levente.kardos2@uni-corvinus.hu \\ (Received 31 $1^{\text {st }}$ August 2011; accepted $17^{\text {th }}$ October 2011)
}

\begin{abstract}
Biogas may be produced from communal sewage sludges by anaerobic decomposition. To follow up the decomposition processes enzyme activity tests have been applied. It is advantageous to use these activity tests if there are frequent substrate-, or specific organic matter load changes in the digesting towers. For describing the total activity of the cells, dehydrogenase-, while for following up the frequent substrate changes protease-, lipase- and cellulase enzyme activity analyses have been carried out. No internationally accepted standards are available for testing the enzyme activity of sewage sludges. Thus, in our experimental work we modified the enzyme activity analyses described earlier in the special literature for the tests of other than sewage sludge samples. Our enzyme activity tests can be completed quickly and at a relative low cost, thus it is possible to use them in generally equipped wastewater treatment laboratories also.
\end{abstract}

Keywords: sludge, dehydrogenase, lipase, protease, cellulase

\section{Introduction}

In a communal wastewater treatment plant large volumes of sewage sludge occur from which it is possible to produce biogas by anaerobic fermentation. The energetical use of the produced biogas takes a part in the increasing power independence of the plant as burning the produced biogas the total electric power demand of the plant can be met. Treated or untreated sewage sludge can be made extensive use like agricultural soil improving material too (Yudhistra Kumar and Vikram Reddy, 2010). Biogas is a very important renewable energy source in the world. For example in India the government sponsors the building of furthur 3 million familly scale biogas reactors by 2012 (Raghuvanshi et al., 2008). For this reason an increase both in biogas volume and in heating power is an important goal, and may be answered if the anaerobic fermentation process is understood more throughfully. In the course of our research the enzyme activities of sludge samples originating from anaerobic sewage sludge fermentation plants were studied under different operating conditions - which were described in an our former article (Kardos et al., 2009). In the present article enzyme activity 
measurements used for following up the anaerobic decomposition are described in more details.

With the enzyme activity measurements the initial hydrolysis processes of the anaerobic decomposition can be described - being also the rate determining step of the complete process (Thiel at al., 1968).

\section{Material and methods}

The sludge samples originated from the South-Pest Wastewater Treatment Plant (Budapest, Hungary) where communal wastewater is treated. The Plant has a capacity of $80000 \mathrm{~m}^{3} /$ day. One thermophilic, three mesophilic anaerobic full scale fermenters and three pilot plant scale fermenters can be found in the Plant. The thermophilic plant tower is of $2000 \mathrm{~m}^{3}$ while each mesophilic tower has a capacity of $2600 \mathrm{~m}^{3}$. The average operating temperature of the thermophilic tower is $55^{\circ} \mathrm{C}$ and it is $35^{\circ} \mathrm{C}$ in the case of the mesophilic towers. The useful capacity of the pilot plant scale fermenters is $1.5,2.0$ and $2.5 \mathrm{~m}^{3}$ respectively, and their temperature can be varied. For our experiments the anaerobic sludge was taken from all these fermenters, however here only some measured data are shown - as examples - related to sludge samples derived from the pilot plant scale fermenters.

Our enzyme activity analyses covered dehydrogenase enzyme activity typical of the total activity of the cells, and three substrate specific enzyme activities; i.e. protease-, lipase- and cellulase enzyme activities. The analysis of the substrate specific enzyme activities was reasoned by the frequent changes in the protein- and fat content of the sludge. The cellulase enzyme activity was analysed only in those cases when the sewage sludge and the horticultural wastes had been fermented together (studying cosubstrate effect).

There are no internationally accepted standards for the enzyme activity tests of the anaerobic sewage sludge samples, thus our used formulas were based on earlier prescriptions. Each enzyme activity measurement was thus optimised in our adopted recipes related to the applied temperature, incubation period and also the sludge mass (latter expressed as dry material /reagent unit ratio). The blank samples composition and role were also investigated, and the proper one was selected for each enzyme activity test type.

The basis for the measurement of the dehydrogenase enzyme activity typical of the total activity of the cells was provided by the Hungarian Standard MSZ-081721/3:1986. As this standard described the determination of the actual dehydrogenase enzyme activity of soil samples, we adapted the method of this measurement to anaerobic sludge samples. In the course of our work the testing results of Skujins (1976), García et al. (1993) and Griebe et al. (1997) were also used. The principle of the measurement is - as a result of the process catalyzed by the enzyme - that 2,3,5triphenyltetrazolium chloride (TTC) transforms to a red colour triphenyl-phormazane (TP), the quantity of which could be spectrophotometrically measured. Knowing the measured sludge quantity, the produced triphenyl-phormazane concentration is converted to specific units of $\mathrm{mg} \mathrm{TP} / \mathrm{g}$ organic matter/hour.

To follow up the enzyme activity, $1 \mathrm{~cm}^{3}$ TTC-solution of $1 \mathrm{~m} / \mathrm{m} \%$ was added to the sludge samples in addition to the saturated $\mathrm{NaHCO}_{3}$ puffer solution. Sludge samples of $0.5,1.0,2.0$ and $4.0 \mathrm{~cm}^{3}$ were used in our series of experiments. Each case the blank sample was further treated in the same way but of course no substrate had been added 
yet. Also the effect of a change in the incubation temperature was analysed. The original recipe suggested a temperature of $37^{\circ} \mathrm{C}$. For studying the dependence on temperature, four temperatures were selected; i.e. room temperature $\left(20^{\circ} \mathrm{C}\right), 37^{\circ} \mathrm{C}$ (temperature of the mesophilic sludge treatment), $45^{\circ} \mathrm{C}$ and $55^{\circ} \mathrm{C}$ (temperature of the thermophilic sludge treatment).

We analysed the incubation period too. The incubation period was varied between half an hour to four hours, after which the enzyme activity of each sample was stopped by absolute ethanol. Immediately before ethanol addition, $1 \mathrm{~cm}^{3}$ substrate was added to the blank samples. After 10 minutes of sedimentation, the samples were filtered and the red solutions were photometered at $485 \mathrm{~nm}$ against ethanol.

The principle of the protease enzyme activity measurement is the follow up of the protein (casein) transition to amino acid (tyrosine). The protease activity measurement of sewage sludges was described by Thiel and Hattingh (1967). In our series of experiments each sample contained $1 / 3$ volume part of sludge sample, $1 / 3$ volume part substrate $(0.25 \mathrm{~m} / \mathrm{m} \%$ casein-solution $)$, and $1 / 3$ volume part distilled water. After incubation at room temperature for 1 hour (according to the original recipe) the reaction was stopped by trichloroacetic acid. After alkalization following filtering - due to the separating iron precipitate - it was filtered again and after adding Folin-reagent to the sample the appearing blue colour was measured at $660 \mathrm{~nm}$ in comparison to the blank sample. The anaerobic sludge treated in the above ratios without incubation served as a blank sample following the immediate trichloroacetic acid treatment. The measured data are expressed in $\mathrm{mg}$ tyrosine/g organic matter/hour units.

Also in the case of the protease enzyme activity tests, the volume of the sludge sample was changed $\left(0.5,1.0,2.0\right.$ and $\left.4.0 \mathrm{~cm}^{3}\right)$. In another test series the incubation temperature was altered; in this case also the applied temperatures were the followings: room temperature $\left(20^{\circ} \mathrm{C}\right.$ on an average $) ; 37^{\circ} \mathrm{C} ; 45^{\circ} \mathrm{C}$, and $55^{\circ} \mathrm{C}$. The incubation period was selected between half hour and four hour. In addition the appropriate concentration of the trichloroacetic acid and the rate of the alkalization following the precipitation with trichloroacetic acid were also analysed. We adjusted the optimum $\mathrm{pH}$ of the samples. The blue colour appears immediately after the addition of the Folin-reagent and can be measured at $660 \mathrm{~nm}$. Also the time dependence of the blue colour stability was tested when the intensity variation of the blue colour was being studied for 40 minutes.

For measuring lipase enzyme activity, the work of Vorderwülbecke et al. (1992) and Li and Chróst (2006) were used as a basis. For the measurement, the emulsion of two reagent (containing 4-nitrophenyl palmitate -NPP- as substrate) solutions had to be prepared that was added to a predetermined portion of the supernatant layer of the centrifuged sludge. After one hour incubation at $45^{\circ} \mathrm{C}$ (according to the original recipe), the absorption of the sample was measured at $410 \mathrm{~nm}$ in comparison with the blank sample. In the course of the enzyme processes, the 4-nitrophenyl palmitate - being present as a substrate - was transforming to 4-nitrophenol (NP) that could be measured spectrophotometrically. The activity was expressed in 4-nitrophenol mass produced hourly by $1 \mathrm{~g}$ organic sludge. Improving the recipe in this case also the incubation temperatures and the change of incubation period as described above were studied.

In measuring the cellulase enzyme activity, the work by Lee et al. (2002) and Rivard et al. (1994) served as a starting point. In the course of the measurement, the cellulose decomposition of the fermented sludge was examined at $37^{\circ} \mathrm{C}$ for an incubation period of 24 hours according to the original recipe. Each case an easily decomposing cellulose 
by-product (carboxymethyl cellulose, CMC) and ground grass dried to a mass steadiness - that can be decomposed with more difficulty - were added to a portion of the sludge sample. After incubation the suspension was centrifuged. In the centrifuged product the glucose - liberated from the cellulose products - was determined with the addition of a dinitro-salicylic acid (DNS) reagent. The sample got brown to an extent which depended on its reducing sugar content and was photometered at $550 \mathrm{~nm}$. Glucose originating from the decomposition of the sludge was corrected with a blank sample containing no substrate. The evaluation was made with the aid of glucose calibration. The activity was stated in glucose quantity liberated daily by a unit of organic sludge.

For improving the recipe, in this case also the incubation temperatures and the change of the incubating period were studied.

\section{Results}

Among the results presented in the followings, data of minimum 25 samples referring to each test series are described. The examined sludge had an average $\mathrm{pH}=7.1$ \pm 0.5 , average dry material content $56.8 \pm 9.6 \mathrm{~g} / \mathrm{kg}$, average organic material content $26.7 \pm 7.6 \mathrm{~g} / \mathrm{kg}$.

During the analysis of the dehydrogenase enzyme activity rising the volume of the sludge samples - that is sludge mass ratio related to the applied reagent quantity - a nonlinear increase in the measured absorbances was observed. We stated that in the case of $1 \mathrm{~cm}^{3}$ substrate solution ( $1 \mathrm{~mm} \%$ TTC) the reliable sludge volume was $1 \mathrm{~cm}^{3}$ testing sludge samples having the earlier mentioned organic mass concentration. In line with raising the incubating temperature an increasing enzyme activity was indicated by the higher absorbance values. From our results it was concluded that this enzyme tests can be made at any temperature between 30 and $55^{\circ} \mathrm{C}$. In mesophilic anaerobic fermentation the incubation at about $37^{\circ} \mathrm{C}$, while in thermophilic fermentation incubation at about $55^{\circ} \mathrm{C}$ is suggested, as these temperatures are near to the optimal life conditions of the mesophilic and thermopilic bacteria. The optimal incubation time determined at each temperature turned to be 1 hour.

On the basis of our protease activity measurement, in the case of the used substrate concentration, the $2 \mathrm{~cm}^{3}$ sludge sample volume having the given mass concentration the most suitable. On the basis of our experiences - independently of the mesophilic or thermopilic origin of the sludge - considering both the activity and the reproducibility the most advantageous temperature turned to be $37^{\circ} \mathrm{C}$. The $3 \mathrm{~cm}^{3} 10 \mathrm{~m} / \mathrm{m} \%$ trichloroacetic acid concentration included in the original recipe was not adequate, thus a concentration of $15 \mathrm{~m} / \mathrm{m} \%$ was used. Due to application of both acid and Folinreagent (diluted to $1: 1$ ), the samples had to be alkalized, thus $3 \mathrm{~cm}^{3} 2 \mathrm{~mol} / \mathrm{dm}^{3} \mathrm{NaOH}$ solution was used before adding the Folin-reagent. The ratio of Folin-reagent and sample was in volume: $0.1: 1$. On the basis of the time dependence analysis for the occurring blue colour it can be stated that the blue colour had been stabilized after a period of approximately 15 minutes.

As a result of the lipase enzyme activity tests it can be stated that - due to the activity and the reproducibility data - the suitable incubation temperature is $45^{\circ} \mathrm{C}$, and it does not depend on the preliminary fermentation temperature. The optimum incubation time was between 60 and 80 minutes. 
Our cellulase analyses proved that the suitable incubation temperature is $37^{\circ} \mathrm{C}$. We suggest an incubation period of 24 hour which can be appropriately applied also by an average laboratory of a wastewater treatment plant. The incubation period of 24 hours is reasoned by the fact that during this period the hydrolysis of cellulase molecules which can be decomposed with difficulty - will be suitably completed.

Here we show some results of vegetable waste and sludge cofermentation (cosubstrate effect) from our pilot plant scale experiments. It can be seen, that during the experiment the cellulase- and protease enzyme activities showed a close correlation with the alteration of the daily gas volume (Figure 1). The changes in substrate load were properly indicated by our enzyme activity measurements (organic matter load varied: $5.24 \pm 1.4 \mathrm{~kg} / \mathrm{m}^{3} \cdot \mathrm{d}$ ). The supply of the grass waste was preceded by a control period of 36 days during which only sludge was added. The control period was followed by a grass supplying period of 76 days meanwhile each working day $1.5 \mathrm{~kg}$ dried ground grass together with $200 \mathrm{dm}^{3}$ sludge was added. On the basis of our tests it can be stated that the simultaneous sludge and grass feeding presented suitable nutriment for the anaerobic microbe population.

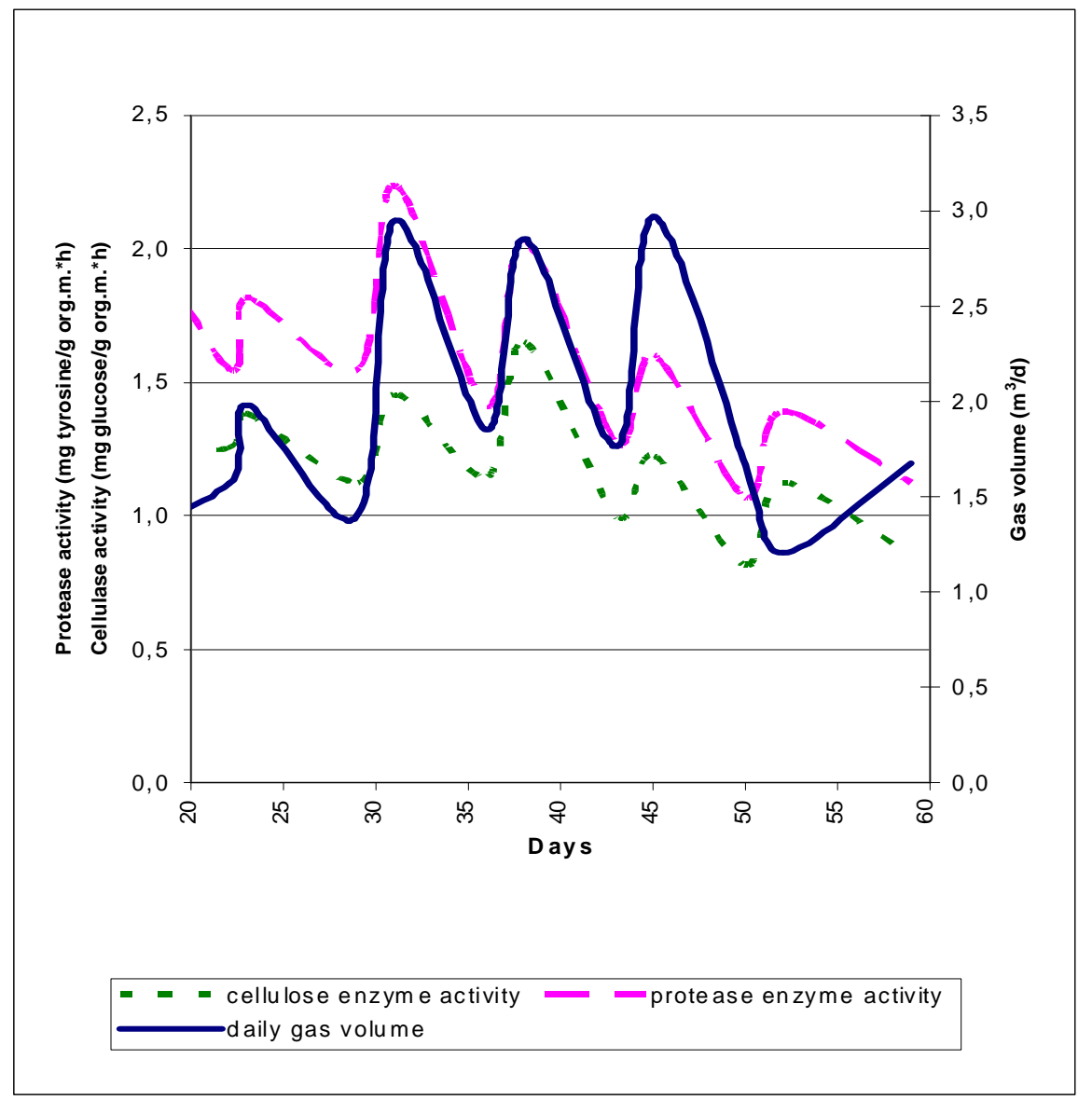

Figure 1. Variation of cellulase and protease enzyme activities in a selected experimental period in pilot plant scale reactor (org.m. = organic material)

Our observations supported that the decomposability of a substrate can be described by the hydrolytic enzyme activity as the speed of the substrate decomposition is the function of enzyme activity, and this is an important condition for biogas 
transformation. More results of full scale and pilot plant fermentation are published elsewhere (Kardos et al, 2009).

\section{Summary}

As a summary our experiences on the recipe modifications are described in Table 1.

Table 1. Summary of the enzyme activity tests (tested sludge: $p H=7.1 \pm 0.5$, average dry material content $56.8 \pm 9.6 \mathrm{~g} / \mathrm{kg}$, average organic material content $26.7 \pm 7.6 \mathrm{~g} / \mathrm{kg}$ )

\begin{tabular}{|c|c|c|c|c|c|}
\hline Enzyme & Substrate & $\begin{array}{c}\text { Product of } \\
\text { metabolism }\end{array}$ & $\begin{array}{c}\text { Sludge } \\
\text { volume }\left(\mathrm{cm}^{3}\right)\end{array}$ & $\begin{array}{l}\text { Incubation } \\
\text { temperature }\end{array}$ & Others \\
\hline Dehydrogenase & $\begin{array}{l}\text { 2,3,5-triphenyl- } \\
\text { tetrazolium } \\
\text { chloride (TTC) }\end{array}$ & $\begin{array}{l}\text { triphenyl- } \\
\text { phormazane } \\
\text { (TP) }\end{array}$ & 1 & $\begin{array}{c}\text { In case of a } \\
\text { mesophilic } \\
\text { sludge: } 37^{\circ} \mathrm{C} \text {, in } \\
\text { case of a } \\
\text { thermophilic } \\
\text { sludge: } 55^{\circ} \mathrm{C}\end{array}$ & $\begin{array}{c}\text { Incubation for } 1 \\
\text { hour }\end{array}$ \\
\hline Protease & casein & tyrosine & 2 & $\begin{array}{c}37^{\circ} \mathrm{C}, \\
\text { independently } \\
\text { of the } \\
\text { preliminary } \\
\text { sludge } \\
\text { fermentation } \\
\text { temperature }\end{array}$ & $\begin{array}{l}\text { Treatment with } \\
15 \mathrm{~m} / \mathrm{m} \% \\
\text { trichloroacetic } \\
\text { acid and } 2 \\
\text { mol/ } / \mathrm{dm}^{3} \mathrm{NaOH} \\
\text { Incubation for } 1 \\
\text { hour }\end{array}$ \\
\hline Lipase & $\begin{array}{c}\text { 4-nitrophenyl } \\
\text { palmitate (NPP) }\end{array}$ & $\begin{array}{l}\text { 4-nitrophenol } \\
\text { (NP) }\end{array}$ & $\begin{array}{l}1 \text { (liquid } \\
\text { extract of } \\
\text { sludge) }\end{array}$ & $45^{\circ} \mathrm{C}$ & $\begin{array}{l}\text { Incubation } \\
\text { between } 60 \text { and } \\
80 \text { minutes }\end{array}$ \\
\hline Cellulase & $\begin{array}{c}\text { Carboxymethyl } \\
\text { cellulose (CMC) } \\
\text { or grass }\end{array}$ & glucose & $\begin{array}{l}2 \text { (liquid } \\
\text { extract of } \\
\text { sludge) }\end{array}$ & $37^{\circ} \mathrm{C}$ & $\begin{array}{l}\text { Incubation for } \\
24 \text { hours }\end{array}$ \\
\hline
\end{tabular}

In case of the substrate specific enzyme activity analyses, the stated incubation temperatures have not shown any relationship with the preliminary fermentation temperature of the sludge; it is explained by the fact that in these cases the fat-, proteinand cellulose contents of the sludge are more determinative.

Acknowledgement. We express our thanks to the staff of the Wastewater Treatment Plant of South Pest, for the operation of the plant- and pilot plant scale reactors and the Research and Development Group for their assistance. This research was supported by the TÁMOP 4.2.1/B-09/01/KMR/2010-0005 project.

\section{REFERENCES}

[1] Analysis of soil biological activity by method of dehydrogenase enzyme activity (1986): Soil analysis of agricultural land treated with sewage and sewage sludge. MSZ-081721/3-86 (Hungarian Standard), Budapest, Hungary.

[2] Griebe, T., Schaule, G., Wuertz, S. (1997): Determination of microbial respiratory and redox activity in activated sludge. - Journal of Industrial Microbiology and Biotechnology 19(2): 118-122. 
[3] García, C., Hernandez, T., Albaladejo, J., Castilla, V., Roldan, A. (1998): Revegetation in senierid zone: influence of terracinn gand organic refuse on microbial activity. - Soil Science Society of America Journal 62: 670-676.

[4] Kardos, L., Palkó, Gy., Oláh, J., Barkács, K., Záray, Gy. (2009): Operation control of anaerobic digesters on the basis of enzyme activity tests. - Water Science and Technology 64(4): 957-964.

[5] Lee, S.-M., Lin, J., Koo, Y.-M. (2002): Hydrolysis of paper sludge using mixed cellulase system: Enzymtic Hydrolysis of paper sludge. - Biological Systems Engineering, ACS Symposium Series 830: 121-138.

[6] Li, Y., Chróst, J. R. (2006): Microbial enzyme activities in anaerobic activated sludge model - Enzyme Microbiological Technology 39(4): 568-572.

[7] Raghuvanshi, S., P., Raghav, A. K., Chandra, A. (2008): Renewable energy resources for climate change mitigation. - Applied Ecology and Environmental Research 6(4): 15-27.

[8] Rivard, C. J., Nieves, R. A., Nagle, N. J., Himmel, M. E. (1994): Evaluation of discrete cellulase enzyme activities from anaerobic digester sludge fed a municipal solid waste feedstock. - Applied Biochemistry and Biotechnology 45-46(1): 453-462.

[9] Skujins, J. (1976): Enzymes in soil. - In: Mc Laren A.D., Peterson, G.H. (eds.). Soil Biochemistry, Marcel Dekker, Inc. New York, USA: 371-414.

[10] Thiel, P. G., Hattingh, W., H. J. (1967): Determination of hydrolytic enzyme activites in anaerobic digestion. - Water Research 1: 191-196.

[11] Thiel, P., G., Toerien, D. F., Hattingh, W., H., J., Kotzé, J. P., Siebert, M., L. (1968): Interrelations between biological and chemical characteristics in anaerobic digestion. Water Research 2: 393-408.

[12] Vorderwülbecke, T., Kieslich, K., Erdmann, H. (1992): Comparison of lipases by different assays. - Enzyme Microbiological Technology 14: 631-639.

[13] Yudhistra Kumar, A., Vikram Reddy, M. (2010): Effects of municipal sewage on the growth performance of Casuarina equisetifolia (Forst. \& Forst.) on sandy soli of east coast at Kalpakkam (Tamil Nadu, India) - Applied Ecology and Environmental Research 8(1): 77-85. 